\title{
Area Studies in the Age of Globalization
}

\author{
David L udden
}

University of Pennsylvania

\section{Introduction}

The body of knowledge that we call "area studies" is supported by little theory except that provided by the academic disciplines that compose it. Its history goes back to the beginnings of European imperial expansion, but area studies only came on the scene with the cutting of the world into national states that covered the map after 1945. Intellectual assumptions and academic practices in area studies depend on the power of national states to define territories of culture and history. National states provide the primary institutional base for area studies. National interests have justified funding for area studies in the universities, where additional interest arose from the need to understand national identities and cultural pluralism. Area studies could thus be expected to reflect change in the status of the national state, and so it has. Area studies has been deeply disrupted both institutionally and intellectually by challenges to the permanence and authority of national states in the last twenty years. Social movements inside national territories have challenged the legitimacy of existing states, political movements have changed state boundaries, and globalization has undermined the power of states to organize economies and knowledge systems.

In the U.S., area studies came into being to serve national interests that became more global after 1945. In the 1950 s, federal programs and private foundations provided funds to increase American knowledge of world areas to inform the global conduct of U.S. foreign policy, but national interests also included businesses, foundations, and universities 
that all sought to globalize their role in America's world. Before 1945, America's world centered on Europe, though it included East Asia and Latin America, and to a much lesser extent British and French imperial territories in Africa, Asia, and the Middle East. After 1945, a new global U.S. view of the world emerged, and with it, area studies. Specifically, American national interests propelled an American style of area studies and American globalization at the same time.

The Cold War defined America's global context until 1989. ${ }^{1}$ When the Cold War ended and the U.S. government declared itself the victor, university administrators, legislators, and funding agencies questioned the old rationale for area studies. Institutional support for area studies knowledge came to depend on its relevance to a new phase of globalization, as the university, like business and government, sought to expand operations globally in a world where America seemed to have no serious competitors. American scholars in area studies programs, well-endowed with talent and resources, have been forced to create a new foundation for area studies in relation to globalization. The reinvention of area studies is still far from over. Many area studies programs in the U.S. are in the midst of or on the verge of institutional and intellectual crises. This essay provides some history for the intellectual work of rebuilding area studies. ${ }^{2}$

\section{The American Paradigm: Institutions and Funding}

In the 1950 s, area studies, study abroad programs, and international studies disciplines came into being at the same time. Fulbright programs, the Social Science Research Council's area studies programs, university programs to teach languages and area-specific courses, and American overseas research institutes and centers arose on the basis of funding generated by national priorities in Washington. The Title VI program in the Department of Education became the centerpiece of university funding for area studies. Struggles for academic funding henceforth centered on federal allocations and always involved discussions of global politics and the usefulness of area studies for U.S. interests. Since 1970 , the central question in Washington has been whether to maintain funding for established area studies programs. Direct federal funding for area studies (which is only a part of the funding for international educa- 
tion, training, and exchange) totals roughly $\$ 60$ million annually, which is enhanced by federal funds for library materials.

Federal dollars have been concentrated in 115 or so National Resource Centers around the country, supported by U.S. Title VI grants. These grants allow institutions to attract other funding. For instance, the South Asia program at the University of Pennsylvania (Penn) has amassed an endowment whose annual income now approximates $70 \%$ of the value of a Title VI center grant. Penn graduate students supported for their first two years by FLAS (Foreign Language and Area Studies) funding receive support from other university sources for the rest of their studies. Books from South Asia constituted $12 \%$ of the total holdings of the main University library. Faculty appointments based on various department budgets now support a South Asia program at Penn that was originally established in the 1950s in a setting where the only major South Asian subject taught at the university was Sanskrit. Other old Title VI area studies centers for Africa, Latin America, the Middle East, South Asia, and East and Southeast Asia have had similar success raising funds and accumulating assets over the past fifty years, based on federal commitments from the 1950s that have remained substantially in place since then.

Federal allocations came under new critical scrutiny as the end of the Cold War undermined the most effective lobbyist argument on Capitol Hill. Military needs had been the Title VI lobbyists' secret weapon. When Ronald Reagan tried to kill the Department of Education, Secretary of Defense Caspar Weinberger saved it by underlining the strategic importance of international and area studies. Unlike the government, private foundations never stressed a Cold War rationale of area studies, but they displayed it nonetheless when they responded to events in 1989 by raising new questions about the need to maintain area studies. The Social Science Research Council (SSRC) used the end of the Cold War as a rationale for transforming its area studies programs, and openly stated that changes in the world political environment influenced knowledge production in the U.S. academy. The Mellon, MacArthur, and Ford Foundations funded a series of discussions about the future of area studies. ${ }^{3}$ Budget cutting by Congress triggered efforts to protect government funding for international programs, specifically Title VI.

The various institutions involved in area studies faced the challenges of the 1990s each in their own way. Universities analyzed area studies in 
their own local perspectives. At the University of Pennsylvania, for example, discussions about area studies began with the fear that the Title VI program as a whole would die with the Cold War. In 1994, one dean said publicly that if Title VI funding died, so would area studies at Penn, but since then one new Title VI center has come into being with the deans' support and three old centers which lost Title VI funding received emergency attention from deans to re-establish the old area studies programs on new footing. Local finance now seems paramount, rather than national priorities. Universities are responding to market signals from funding agencies, donors, and constituencies composed of alumni, students, and legislatures. At Penn, the old emphasis of area studies programs on producing Ph.D.s has been replaced with a central focus on undergraduate education, with a keen eye to student demand and donor support from ethnic groups. At many universities, local constituency demands are nudging area studies programs into transnational ethnic studies.

At the SSRC, which has served as a sort of national think-tank for area studies, debates have been strictly academic. They focus on the globalization of social science; and they address not only the problem of getting funds but also the task of influencing funding agency priorities, particularly at foundations. Meanwhile, on Capitol Hill, Congress hears arguments about the interests of that mythical voter on Main Street, where federal funding for Hindi, Arabic, Korean, Swahili and the like has to make sense to middle-class America. But in this new political environment, Title VI has not died: in fact, it has grown. Fulbright funding has expanded. Whether this trend will continue under a Bush administration is uncertain, but so far, the cry that America needs to expand its global enterprise has met with sympathy on the Hill. The political importance of area studies institutions around the country, and of the ethnic group lobbies and constituencies, should also get some credit for maintaining area studies funding.

\section{Responding to the Cold War's End}

The fragmentation of the Soviet Union and the quickening pace of economic globalization in the 1990s are now accepted as epoch markers in a contemporary world context set apart from post-World War II decades. The SSRC's Vice President during the early 1990s, Stanley 
Higgenbotham, wrote several essays and gave many speeches on the implications of the end of the Cold War, but discussions about the future of area studies have tended to focus rather on globalization, which has become prominent in American discourse generally. A lurking assumption appears to be that (U.S.-led) globalization has no opposition and dominates the world in which the U.S. academy is now working.

The present historical moment is widely seen to be the start of a new era. Thomas Haskell recently captured a newly-cliched view of recent history by saying: "The bloody contest between capitalism and socialism unexpectedly came to an end in 1989 after a struggle that gripped the world for a century and half." 4 Eric Hobsbawm called 1989 the end of "the age of extremes," saying that "citizens of the fin de siecle tapped their way through the global fog that surrounded them, into the third millennium $[\ldots]$ certain $[\ldots]$ that an era of history had ended." Then he added: "They knew very little else." 5

Like many legislators and intellectuals, the leaders at the SSRC and the Ford Foundation understood the end of the Cold War to mean that new modes of knowledge production were needed. By 1989, the SSRC and American Council of Learned Societies (ACLS) had sustained a dozen or so area studies joint committees for thirty years. These multi-disciplinary area studies committees, composed of faculty representing U.S. area studies programs, distributed about half of the SSRC operating budget to generate short-term grants for conferences and research publications. Annual reports of the SSRC indicate that these committees had an impressive record of productivity and influence. The new post-1989 critique of area studies initially came from the SSRC president, David Featherman, in the form of disciplinary objections to area studies in general. He argued that disciplinary social sciences were more universally applicable, globally useful, and more worthy of support than area studies. His argument against area studies favored "hard" social sciences like economics, political science, and sociology, which use statistical data, formal models (often mathematical), and positivist, explanatory theory. Featherman proposed reducing the power of the SSRC-ACLS joint committees to allow the central administration to reallocate funds more favorably to social science-oriented research and training.

In 1996, the SSRC, under a new president, Ken Prewitt, eliminated joint committees altogether and began to tap its way through the fog 
toward a new and looser structure of "regional advisory panels." Prewitt clearly favored more global forms of social science knowledge over established area studies, and he opened up the Councils' options by pulling the plug on the old joint committees. In 1997, using Ford funding, the SSRC and ACLS held a joint meeting, including more than a hundred advisory panel members from all the areas and disciplines represented by the two Councils, for the sole purpose of discussing the current condition and future direction of area studies. The meeting began with a panel that described the present as a turning point in history, and then emphasis fell upon globalization and the transformation of Eastern Europe and the former Soviet Union. At the end of the meeting, area studies survived critical scrutiny. It did so not because existing programs were taken to be satisfactory, but rather because participants repeatedly substantiated the need for area-specific forms of knowledge in social science and humanities disciplines.

At the SSRC and elsewhere, the intellectual and institutional trajectories of area studies are now diverse and uncertain. Federal and foundation funding have survived under sharpened financial pressure and political scrutiny. The SSRC maintains a loose experimental structure of regional advisory panels and has now centralized the financial decision-making that was previously dispersed among joint committees. Its goal at present is to internationalize social science research collaborations in order to break area studies out of old patterns defined by national territories and U.S. national interests, in recognition of the increasing trend of internationalization within the scholarly community. ${ }^{6}$ The Ford Foundation made similar moves. The Chronicle of Higher Education reported in 1997 that Ford Foundation president Susan V. Berresford "believes that the foundation should devote more of its resources to supporting area studies programs and funding research into global issues."7 Then Ford initiated a "Crossing Borders" program with funding totaling \$25 million over a six-year period to support new initiatives to revitalize area studies. The program announcement says that Ford has two aims in this program: "first, to support intensive study of particular languages, cultures, and histories, building on the first half-century of work in area studies; and second, to foster innovative thinking and practices related to the field of area studies itself, through a variety of partnerships, as well as disciplinary and other 'border-crossings.' "8 


\section{Globalizing Social Science}

Among social sciences, political science logically paid the most attention to problems posed by the Cold War's end, which had affected this discipline most immediately. Debates in PS: Political Science E Politics focused particularly on the Middle East ${ }^{9}$ and on the role of theory in comparative politics. ${ }^{10}$ Christopher Shea catches their tone with his headline: "Political scientists clash over value of area studies: theorists say that a focus on individual regions leads to work that is mushy."11

These debates reproduced an old opposition, between social scientists who support and those who oppose area studies, which had long simmered at the boundaries of disciplines over questions of interdisciplinary collaboration. ${ }^{12}$ But old critiques of area studies ${ }^{13}$ produced a novel outcome in the context of the nineties. Strict disciplinarians like Robert Bates argued that area studies did produce descriptive data that needed to be incorporated into universal theories and disciplinary methodologies; toward this end, he promoted rational choice theory. Interdisciplinary cultural specialists like Arjun Appadurai argued that new transnational processes affected every world region, forcing social science to study globalization itself in area-sensitive terms; toward this end, he promoted an amalgam of anthropology, history, and cultural studies such as that which is prominent at the University of Chicago. ${ }^{14}$

As area studies entered the new age of globalization, three academic arguments about what was needed came to the fore, most explicitly at the SSRC. "Hard" social science disciplinarians sharpened their old opposition to area studies with new confidence in the universal utility of their theories and methods, but area specialists among them made theoretical arguments for incorporating world areas into social science knowledge. "Soft" social sciences, especially history and anthropology, had been as deeply involved in area studies as political science, but less disrupted by the Cold War's end and, in collaboration with the humanities and cultural studies, more receptive to forms of knowledge from various world regions. As a result of the academic influence of four decades of area studies in U.S. universities, opposition between the hard and soft social sciences produced new intellectual space for the formation of global knowledge that combines universal theory with local substance. This new mode of knowledge production was awkwardly dubbed "context-sensitive social 
science" at the SSRC. Context-sensitivity gave various social sciences and humanities disciplines a theoretical place to meet for discussions about area studies.

Social scientists can now collaborate with (or, at least tolerate) scholars who pursue "mushy" area studies forms of interdisciplinary knowledge by simply agreeing that there is an emerging formation of global social science that incorporates a cultural studies agenda. This seems to be the framework in which Ford and the SSRC propose to reconfigure area studies. This new form of social science has the potential of achieving global reach without being imperialistic, or even domineering. It is international in its embrace and participation; and it includes all the multicultural voices of race, class, gender, ethnicity, nationality, religion, sexual orientation, and such. It combines the collective powers of empirical, deductive sciences with the critical powers and descriptive, interpretive subtleties of cultural studies. Global in vision, arguments, and relevance, it is local in its data, application, and humanity. It keeps the humanities-language and literature disciplines - at one remove, however, because after all, it is a kind of social science. This global knowledge is not the same as area studies because it is not defined by an a priori separation of world territories. Its attitude to area studies is essentially utilitarian. It defines a domain outside area studies, encompassing area studies knowledge, giving it new meaning and utility, so that area studies can participate in a new global agenda.

However "context-sensitive" social science may become, a disjuncture remains between area studies and global studies. Area-focused disciplinarians in history and anthropology (including folklore), for instance, can remain committed to area studies as an end in itself. Their attention to global forms of knowledge- to world history, global issues, or transnational processes-brings them into a conversation with a context-sensitized social science, but they remain committed to the particularity of a specific world region, whether it be defined by national state boundaries, cultural boundaries, or transnational flows. At the same time, disciplinarians who are actually hostile to area studies as an end in itself can now accept area studies as a means to higher scientific ends. 


\section{The U.S. GIobal University}

Collectively, colleges and universities need to reproduce all the various kinds of skills and knowledge that constitute area studies. Though each institution does not need to provide the entire package on its own, there is currently no national mechanism for coordinating area studies programs. Institutions confront their new challenges individually amidst a diverse set of local financial considerations, which include market demand for the knowledge they offer. In hard money terms, professions, sciences, and undergraduates most preoccupy the institutions of higher education that must sustain area studies.

For professional schools and the sciences, area studies programs are at best places for the application of universal knowledge. Some regions of the world do have a place in the conduct of some sciences-for instance, geology —and there are many international scientific collaborations in the Fulbright program. Environmental scientists spend time in many world areas, but they are not concerned with area studies knowledge that pertains to education and training in language and culture. Scientists enter the Fulbright Senior Scholars program because work overseas is useful to them; and indeed, humanizing science was part of Senator Fulbright's dream. There are some people from business schools on Fulbrights, and some business schools do receive support in their international efforts from the Department of Education. The University of Pennsylvania's erstwhile international studies Title VI program was located in the Wharton school, and the Lauder Program at Wharton specializes in using area studies to train international business executives.

Professional schools and sciences command vast financial resources in a way that is actually hostile to area studies, except as an adjunct. Professional schools do not need area studies knowledge in the same way that social science and humanities disciplines do, and they will not pay for its production. While business schools might be willing to train students in language and area knowledge for their specific professional purposes, they usually do not go beyond that. Even social scientists who are contextsensitive usually work in departments which are not. Social science departments typically use area studies knowledge, but do not want to pay for its production. In budget competitions, they join the sciences and professions in their support of universal knowledge with global reach. 
One new financial base for area studies knowledge is coming from undergraduates who want ethnic studies, heritage studies, comparative literature, women's studies, cultural studies and new forms of international knowledge. All area studies programs benefit to some extent from this new demand. Area studies programs seek financial support from the appropriate "community" groups for institutional initiatives like language instruction. Asian studies programs look for funding for new faculty from Asian-American and Asian communities in America. African studies programs look for support from schools of medicine, nursing, and public health that are involved in research and training programs in Africa. African-American and African studies programs are tending to merge. Many undergraduates who seek heritage courses in Latin American or Indian studies are also pre-professionals who will work in a foreign country during their career. These are natural constituents for the institution of area studies within globalization.

Perhaps the most important shift represented by the globalization of area studies is the reduced role of the national state in its organization, finance, and ideology. The global agenda provides many new opportunities for area studies to serve the social sciences, business schools, public policy institutes, medical schools, NGOs, United Nations organizations, private enterprise, and governments. Universities are thus developing new support systems for area studies that cross the boundaries among schools and allow practitioners of all the disciplines to expand their powers to operate anywhere in the world. This has been happening for ten years, and many major area studies programs operate today inside multi-school institutes like those at Berkeley, Michigan, and Wisconsin. The university centralization of the administration of area studies has been moving ahead more rapidly even than centralization at the SSRC and Ford Foundation.

\section{The New Globalism}

Current trends indicate that area studies will develop by making a case for itself in the constellation of interests and forms of knowledge that converge on globalization. Global interests will not support area studies on their own because they are at best opportunistic in their appreciation of area studies and they will look to buy its knowledge without bearing the cost of its reproduction. For agents and scholars of globalization, 
moreover, the territoriality that is built into area studies is odious, and knowledge that is attached in and for itself to a specific territory is archaic, limited, low-tech and lowbrow. Constraints on the flow of ideas and information such as those built into myriad foreign languages constitute obstacles for globalism, and old-fashioned area studies, like old-fashioned states, obstruct the movement of knowledge across their borders. A monolingual internet world is more their style.

The new globalism is trans-national and post-national; it associates state boundaries with restraint, confinement, and limitation. In the World Bank's 1997 World Development Report, for instance, we can read instructions for state managers, but beyond its function for the world economy, the state seems unnecessary. In globalization circles, the idea that a national state is a moral guardian of national interests, identities, and well-being seems to be a thing of the past. A new hyper-capitalist critique of the nation state has joined a leftist critique of national state power. ${ }^{15}$ Stripping away the state would seem to "liberate" peoples and localities for participation in globalization.

Yet globalism as a form of knowledge conceals the territorial dimensions of globalization itself and thus the historical position of area studies within it. A new home for area studies in a world of globalization will begin to emerge as we better understand the long historic interaction of area studies knowledge and the process of globalization. Area studies knowledge did not begin with the Cold War but rather emerged with modernity, and constituted not only nationality, but also imperialism. Since the Enlightenment, imperial territorialism has elevated scientific, universal knowledge that encompasses and surpasses all the narrow, traditional, partisan, and idiosyncratic forms of medieval and early modern knowledge that preceded it and which have challenged modernity. Modern nationalism combined scientific, imperial knowledge as it emerged in the form of various academic disciplines and used a populist hyper-enchantment of tradition to substantiate national claims to territory.

After World War II, the earth was blanketed with nation states for the first time in human history. Divided among regions of culture, history, and political economy, this new world of nation states provided a grounded reality for the conceptualization and organization of area studies knowledge. Knowing all the regions of the world became the key to twentieth-century globalization, which embraced national territories of 
culture and power that were subjects of area studies. A big shift in the nation-state system would necessarily destabilize area studies, so closely had the two been linked; and after 1989, such a destabilization did occur. However, this shift continued a process of globalization that actually began long before and whose pace has actually been faster at various times in the past than it is today-for instance, between 1880 and $1914 .{ }^{16}$ What is new today is not the fact of globalization, but rather its recognition as a central historical process and its utilization as a theoretical basis for efforts to reorganize knowledge and power in the world.

As an ideological phenomenon, globalism expresses ambitions that use area studies knowledge but reject any aspect of area studies that prevents a comprehensive comprehension of the world. However much area studies may need to pitch itself into globalization, globalism does not provide a stable intellectual or institutional home for modern area studies scholarship.

\section{Real Life in Global Territory}

Though the U.S. is the home of the new globalism, U.S. intellectual life and culture is at one and the same time isolationist and expansive, parochial and imperial. U.S. public support for the U.S. worldwide war machine coexists with a small-town fetishism for intensely local, face-to-face, peaceful, patriarchal family-style, "we don't even lock the doors" social order that U.S. media call "the American way." Much the same can be said for hometown cultures of British and French imperialism in the nineteenth century. Nationalist territoriality and globalization always use one another, and imperial territorialism includes and even fosters its own opposition at home and abroad. Questions about perspective, intention, experience, and participation in globalization emerged after World War II, as Americans entered the world of old empires, and area studies inherited all the complexities of U.S. global territory. Area studies scholarship includes both globalizing and isolationist national tendencies.

The term "globalization" defies precise definition but conveys a sense that international forces-technological, economic, and culturaldrive history around the world, producing the possibility that humans may create a global society and also provoking fear that social life will be dominated by forces beyond the control of national governments within 
which people see the possibility of democracy and self-determination. Globalization is an impersonal, objective process, unfolding out there in the world; but it is also a personal project for people who seek to create an integrated world economy and culture. Some people see these makers of globalization as history's visionary leadership; others see them as dreadful imperialists.

Today's proponents of globalization are also its leading experts and leading advocates of globalism in social science. Opportunities and anxieties in centers of global power preoccupy its experts. The world of wide open opportunities for U.S. enterprise also begets anxiety about chaos and barbarism, which in turn justifies national investments in global military and political power, as in Robert Kaplan's now-famous 1994 article in The Atlantic Monthly. ${ }^{17}$ More pervasive chaotic global movement-described politically by J. Rosenau and culturally by Arjun Appadurai ${ }^{18}$ — give the simultaneous double impression that globalization has no direction, center, or guiding logic, and that globalization is moving out from centers of international financial and media power according to the universal logic of business competition. The desire to find or make order in the chaos of the new world economy remains a pervasive theme among scholars of globalization.

Effective economic governance in the postmodern integrated world economy will require a marked strengthening of international institutions that may eventually acquire powers to tax and enforce the law if territorial jurisdictions collapse. Where is the center of the world system today? It appears to be somewhere in the international processes that lie behind the Uruguay Round of the General Agreement on Tariffs and Trade, or GATT, where the World Trade Organization, or WTO was born, in 1995. David Korten argues that the WTO is "the world's highest judicial and legislative body." When fully operational, it will provide a means for any member country to challenge any law of another member country that it believes deprives it of benefits expected from the new trade rules. This includes virtually any law that requires imported goods to meet local or national health, safety, labor or environmental standards that exceed WTO-accepted international standards. ${ }^{19}$

The connection between the WTO and Main Street, U.S.A, indicates local ambivalence about global activity. There is a serious disjuncture between the process and the project of globalization, on the one hand, 
and the territories and communities at the national, regional, and local level, on the other. This gap needs to be sutured by area studies scholarship. One of the central regions of globalization in the contemporary world is the United States, which is occupied predominantly by forms of knowledge and consciousness that are distinctly hostile to and ignorant of the global environment. U.S. political discourse is territorial both in the expansive and in the enclosed sense of that term. Knowledge in the university reflects that disjuncture and alienation, as pointed out brilliantly by Jane C. Desmond and Virginia R. Dominguez, who describe the alienation of American studies from area studies as being in opposition to the study of the "Self" as opposed to the study of the "Other." 20

This contradiction is found within every national educational system, and at lower levels of spatial order within the nested territories that comprise everyday life in a globalized world. Schools accentuate and institutionalize the feeling of being a Texan, a New Yorker, or North Dakotan in America, or a Tamil, a Gujarati, or Bengali in India. Shahid Amin has shown that in India, the village occupies a place in the world of knowledge outside the national past. ${ }^{21}$ But Amin does not tell us that this separation is sanctioned by official knowledge and sustained by the Indian government and by ruling elites, who in India, as well as in America, help to produce the localism and regionalism of political identity. Thus neither territory nor community are natural phenomena. They are socially stratified, with some people participating both on the local and the global levels, and occupying positions of leadership in regions of power, while other people live entirely at the local level and are thus essentially trapped in places they identify as their native space. All the world's territorial powers generate knowledge that both separate and connect people in the globalization process, but globalism as a form of knowledge only captures that small strand of activity and knowledge that pertains to expansive, free movements across the real boundaries within which most people live.

\section{Institutions Fail}

American area studies programs are little islands of academic activity in a sea of American studies of the American Self. Area studies programs are comparatively weak, scattered enclaves of intellectual activity 
oriented toward a world outside America. Their occupants have reacted quickly, if not wisely, to challenges posed by the rising tide of globalization. They have had very little time or opportunity to reflect collectively on their condition. To sustain themselves, they have run for the money. Area studies programs came into being with national funding initiatives, and once established depended heavily on this funding, which allowed them to remain isolated from American studies of the Self. Their intellectual life became connected more to external aspects of America than to its internal politics. As their importance to U.S. globalization diminished, they worked hard to sustain funding locally inside universities. Some raised and strengthened dikes around their little enclaves of expertise. Others began to shift to American studies of the Self by joining ethnic studies programs. Still others learned to swim the heady currents of globalism. The scattered inhabitants of all these little islands that constitute the archipelago of area studies abandoned their old territory because they did not see that their islands together constituted intellectually coherent, political space. Their institutions failed to sustain the promise of area studies.

In the late 1950s, when a new set of funds known as the National Defense Education Act, or NDEA, was directed at the universities to give them a new interest in foreign languages and in foreign area studies, social scientists who were already most involved in foreign area studies- - historians, political scientists, sociologists, geographers, and anthropologiststook this funding to link themselves with language and humanities programs. This produced an alliance between modernization theory and classical orientalism. The social sciences of modernization theory, developmental studies, state building, and the Cold War scholars formed alliances with scholars of classical languages and literatures. With NDEA funding, the universities assisted the classical Chinese, Sanskrit, Hebrew, Persian, and Arabic specialists to develop updated language programs with new teaching and learning techniques and technologies, strategically adding Japanese, Hindi, Tamil, Turkish, Vietnamese, Swahili and the like, according to institutional needs.

In Asian and Middle East studies, classical languages retained their supremacy, and the University of Pennsylvania has, for instance, had a coterie of full professors who specialize in Sanskrit while all of its modern South Asian language teaching is supported by untenurable faculty. By 
contrast, centers in Latin American studies grew up around the interests inherited from a very old U.S. engagement with its colonial territory to the south and from European language studies in Spanish and Portuguese. African studies and Southeast Asian studies were built virtually from scratch. African studies was a most radical innovation, closely followed by Southeast Asian studies, because these new area studies fields had so little to build on within existing faculties when they were founded. They were least encumbered by alliances among old faculty interests in classical and European languages, philology, orientalism, and literary studies.

Troubles over the relationship between area studies and the disciplines arose only in part from a national funding crisis. While federal funding will continue to benefit area studies, all external funding agencies will insist on more and more local institutional support. Universities, however, do not conceptualize their own priorities within a collective of universities that must together produce a certain totality of knowledge. This collective conceptualization of a national university system lay behind federal funding, but it never took root. Now it would be up to the universities to reformulate some kind of collective image of themselves, so that each would contribute rationally to a national or even global process of knowledge production. Knowing their own place in the world of knowledge is essential for this purpose.

Faced with shaky outside funding and seeking support locally in competition with professions, sciences, and social sciences, area studies programs have demonstrated intellectual inadequacy and an incapacity to generate political support. The old institutions of area studies emerged from a set of opportunistic alliances cobbled together across disciplines. These have been very productive-and they still are-but their intellectual output has not been reinvested in the reproduction of intellectual capital for area studies. Arguments in favor of area studies have remained opportunistic, tied to an outmoded rationale for the flow of funding from government and foundations. Thus, when area studies were challenged by the social sciences at the end of the Cold War, the social sciences won, hands down, because area studies had no theory of itself for its self-protection, no intellectual mastery of its own fate.

Global forms of knowledge and their advocates will not generate the funding for area studies unless the necessity for area-specific knowledge is clearly and widely understood. The intellectual benefits of area studies, 
including language learning, have gone to the disciplines rather than being used to enhance the stature of area studies in the universities. Meanwhile, as area studies specialists have worked for local funding, for tenure, and for promotions in their disciplinary departments, they have joined interdisciplinary programs in ethno-history, comparative literature, women's studies, Afro-American studies, ethnic studies, and transnational cultural studies which do not define themselves by area, but rather by the intersection of disciplines. One of the critical arguments for area studies programs - that they provide a productive space for interdisciplinary collaboration-has now been usurped by other interdisciplinary programs. The institutions of area studies - and the process and logic of area studies knowledge production-have not been intellectually reinvented or theoretically reinvested with the creative energies of scholars who were trained in area studies programs. Some scholars have reinvented their institutional and personal interest in area studies territory. African studies in particular has paid attention to its own legacy of productivity, but the volume on Africa and the Disciplines, published in 1993, has no analogue for other world areas; it expresses a specifically African studies intelligence and interest. It does not seek to provide a theory or intellectual rationale for area-specific knowledge or for area studies in general.

There is no theory of area studies or of area-specific knowledge; there is only a set of institutional, personal, and fragmented disciplinary, market, and professional interests that converge primarily on funding. The organizations that should have taken the lead in forming a broad theoretical basis for area studies are the area studies associations-the African Studies Association, Association of Asian Studies, Latin American Studies Association, and Middle East Studies Association-which have done little except tout the importance of their own world area. In the case of African studies, this effort has included exceptional efforts to theorize connections across world areas-most particularly with Latin America, but also, to a lesser extent, Asia. ${ }^{22}$ However, this kind of cross-area work has for the most part been a project within the disciplines of history and anthropology or an effort to increase the vitality of one area studies project by drawing upon its relations with others.

Area studies scholars working within their own disciplines and across disciplines, and to some extent, across areas, have transformed the substance of area studies knowledge significantly in the last twenty years. 
But being divided by discipline and by their separately institutionalized area studies interests, they have not bothered even to describe, let alone to theorize, area-specific knowledge as such. When their funding is threatened, they compete. A broadly-based theory for area studies that would make sense of the historical development of area studies forms of knowledge in a world of globalization would require a kind of collaboration across disciplines and areas that does not yet exist.

\section{A Site for Area Studies}

Potentially, area studies presents an academic counterpoint to globalization and a critical perspective on the new globalism. The kind of area studies knowledge that is a specifically American combination of rustic parochial isolationism and elite imperial expansionism is not merely a feature of globalization, it is also a breeding ground for new global theories and anxieties. Globalization is site specific, and each part of the world constitutes the center of its own global experience. Area studies scholarship is in a position to articulate the territoriality of globalization.

The SSRC solution to the problem of reorganizing area studies is a logical one: to internationalize area-specific scholarship and to extract area studies from its American moorings. Putting globalization in the perspective of all the various regions of the world, rather than seeing it as a singular process emanating from imperialist capitals, reveals a vast patchwork of world territories which have been both increasingly integrated and differentiated during the long history of globalization. Europe, Africa, and China assumed their modern identity as world regions in the context of globalization.

Old conventional wisdom holds that globalization has been driven by European expansion. Between 1917 and 1989, bipolar images of a capitalist-communist opposition in a "world of extremes" kept that conventional wisdom in place by generating an image of the world torn between two opposing camps based in Europe. A more complex landscape of cultural difference and historical differentiation is now coming into view, because bipolarity is dead and people from all world regions now participate in dispersed global discourses running the gamut from eco-feminism and human rights law to arms control and structural adjustment. Non-European contributions to modernity and the world economy are 
becoming more apparent. In this new landscape of world history, some regions and groups are clearly more powerful than others. Some people and regions have more to gain from globalization than others. In much of the world, globalization is feared and hated. In general, it is seen as being distinctly American, and much of its guiding ideology and imagery today is made in the U.S. ${ }^{23}$

Area studies represents an academic articulation of globalization and territoriality outside the United States. Area studies institutions began with imperial intentions, but have moved well beyond them by operating in worldwide academic networks, and benefiting from the arrival of scholars from other world areas who became the cutting edge of area studies in the U.S. As a result, area studies in the U.S. are driven by global networks of scholarship that take cultural differences very seriously. Many American scholars have become partially expatriated by constant travels and studies in countries where they are foreigners at home abroad.

Thus, in the real world, boundaries and differences are widely understood as being permanent and necessary, even when they are shifting and constantly under danger of erasure. The world's non-European languages and literatures are not dying out. Despite Hollywood, many more films are produced in Indian languages than in English. National states continue not only to produce the world's currencies, protect private property, sustain capital accumulation, regulate financial markets, and sponsor national languages and cultures, so that, as the World Bank's 1997 World Development Report says, national states remain essential for the world economy; nationality is a permanent feature of world culture, especially when challenged. Many forces that drive and attack national states operate primarily inside their borders. A well-stamped passport is still the best sign of a global citizen who at every airport feels the scrutiny of the state.

Global intellectuals move among world regions of cultures and states. Globalizing disciplines represent their common language. Area studies embrace the fact that most global citizens live in territories where the local language is not global and never will be. Globalization has always sustained regional difference and particularism, as it does on Main Street, U.S.A. An appreciation of the multiplicity of sites from which world-changing circulatory processes historically emanate needs to anchor the reconceptualization of area studies. In this context, the West is not a single site but rather a set of localities lumped together variously amidst 
a circulation of elements that emanate from various other places. Where does the reification of "the West" or "Europe and the U.S." as a single force in world history come from? What is the location of this theory? Certainly it is enshrined in American social sciences and area studies. It needs some serious reconsideration within area studies.

Globalization is perhaps best defined as a multiplication of sites in which circulatory movements intersect and from which circulatory movements emanate. More sites produce expanding circles of rippling waves that intersect at more sites over time. Globalization is not only a process but also a project, an ideology, and its operations need to be understood in the context of other processes and projects. There is already a critical literature on the globalization project, which indicates that it should not be assumed to provide the intellectual basis for academic studies of the world at the beginning of this century. Herman Daly put the matter simply in his farewell address to the World Bank, in 1994: "Cosmopolitan globalism weakens national boundaries and the power of national and subnational communities, while strengthening the relative power of transnational corporations." 24 If students in each part of the world are going to understand their real "place" in the world, they need to understand that national borders are zones of tension amidst global circulatory processes that change all kinds of boundaries. By transcending the U.S. national mentality, we can explore the various formations of territory, space, locality, region, and identity that define the world and we can begin to expand the scope of area studies and forge creative collaborations among area studies programs in the context of globalization.

\section{Notes}

1 See Noam Chomsky et. al., The Cold War and the University: Toward an Intellectual History of the Postwar Years, New York: New Press: Distributed by W.W. Norton \& Co., 1997.

2 This essay is an effort to pull together information on area studies that might be useful for students, faculty, and administrators in the context of current discussions. It does not reflect academic research on the history of area studies. For a history of Indian studies in the U.S., see India's Worlds and U.S. Scholars: 1947-1997, edited by Joe Elder, Ainslee Embree, and Ed Dimock, published for the American Institute of Indian Studies by Manohar Publishers, Delhi, pp.265-82. 
3 See Fulbright at Fifty, the report of the National Humanities Center Steering Committee on the Future of the Fulbright Educational Exchange Program, July, 1997.

4 Thomas L. Haskell, "The New Aristocracy," New York Review of Books, December 4, 1997, p.47, reviewing Elliott A. Krause, Death of the Guilds: Professions, States, and the Advance of Capitalism, 1930 to the Present, Yale University Press, New Haven, 1997.

5 Eric Hobsbawm, The Age of Extremes: A History of the World, 1914-1991, Vintage, New York, 1996 (first edition, 1994).

6 "Internationalization of the Social Sciences and Humanities: Report on an ACLS/SSRC meeting, April 4-6, 1997," by Itty Abraham and Ronald Kassimir, June-September, 1997.

7 Joye Mercer, "The Ford Foundation shifts its focus and structure," The Chronicle of Higher Education, August 15, 1997, A29-30.

8 http://www.fordfound.org/publications/recent_articles/crossingborders.cfm

9 James A. Bill, "Comparative Middle East politics: still in search of theory," PS: Political Science E Politics, 27:3, 518-19, September 1994. Jerrold D. Green, "The politics of Middle East politics," PS: Political Science \& Politics, 27:3, September 1994, 517-519,

10 Robert H. Bates, "Area studies and the discipline: a useful controversy?” PS: Political Science \& Politics, 30:2, June 1997, 166-170. Chalmers Johnson, "Preconception vs. observation, or the contributions of Rational Choice Theory and area studies to contemporary political science," PS: Political Science \& Politics, 30:2, June 1997, 170-4. Ian S. Lustick, "The disciplines of political science: studying the culture of rational choice as a case in point," PS: Political Science E Politics, 30:2, June 1997, 175-9.

11 The Chronicle of Higher Education, January 10, 1997, 13-14.

12 Richard D. Lambert, "Blurring the disciplinary boundaries: area studies in the United States." American Behavioral Scientist (Special Issue: Social Knowledge: Balancing Specialization and Integration), 33:6, July-August 1990, 712-33.

13 See for instance the series of articles on each world area of area studies in Society, 22, May-June 1985; and James A. Bill, "Area Studies and Theory-building in Comparative Politics: A Stocktaking." PS: Political Science \& Politics, 18, Fall, 1985, 810-12. 
14 See Liz McMillen, "A New Cadre at Chicago," The Chronicle of Higher Education, A10-11: "The University of Chicago has appointed scholars specializing in cultural and regional studies, mainly concerning Asia, to create a new cadre. In an age of changing national boundaries and cultures, it has initiated a new process of constituting the disciplines. This initiative will bring together 40 scholars to form a gender-studies center. The texts are being broadened to include the history of films and medical culture. The University's globalization project inspires rethinking of area studies by focusing on the relationship between regional and national cultures."

15 See Reading Subaltern Studies: Critical Histories, Contested Meanings, and the Globalisation of South Asia, Edited by David Ludden, Permanent Black Publishers, New Delhi, 2001.

16 For a popular account, see Louis Uchitelle, "World Economy Is as Interconnected Today as in 1913," New York Times, April 30, 1998.

17 "The Coming Anarchy: How scarcity, crime, overpopulation, tribalism, and disease are rapidly destroying the social fabric of our planet," Atlantic Montbly, February 1994, 44-76.

18 J. Rosenau, Turbulence in World Politics: A Theory of Change and Continuity, Princeton University Press, Princeton, NJ, 1990; and Arjun Appadurai, Modernity at Large: Cultural Dimensions of Globalization, University of Minnesota Press, Minneapolis, MN, 1996.

19 David C. Korten, When Corporations Rule the World, London: Earthscan Publishers, 1995, p.174.

20 "Resituating American studies in a critical internationalism," American Quarterly, 48, 3, September 1996, 475-91.

21 Shahid Amin, Event, Metaphor, Memory: Chauri Chaura, 1992-1996, Delhi: Oxford University Press, 1996.

22 See Frederick Cooper, "Conflict and Connections: Rethinking Colonial African History," American Historical Review, December 1994, 99, 5, 1516-1545.

23 See Anthony King, ed., Culture, Globalization, and the World-System: Contemporary Conditions for the Representation of Identity, University of Minnesota Press, Minneapolis, MN, 1997.

24 Quoted in Korten, When Corporations Rule, p.173. 